ホソ研究助成
成果報
Hosokawa Powder Technology Foundation ANNUAL REPORT

17103

\title{
ナノキューブを用いた次世代固体酸化物形燃料電池
}

\section{High Performance Solid Oxide Fuel Cell Using Nanocubes}

\author{
研究代表者 Research leader：大原 智 Satoshi OHARA \\ 大阪大学接合科学研究所 特任教授 \\ Joining and Welding Research Institute, Osaka University, \\ Specially Appointed Professor \\ E-mail: ohara@jwri.osaka-u.ac.jp
}

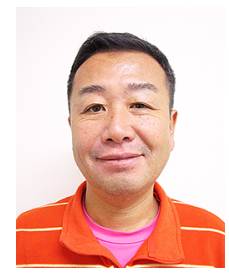

抄 録

水熱反応場でのセラミックスナノ粒子の生成過程において，有機分子の存在割合等を制御すること により，ナノ粒子のサイズだけでなく，形状（結晶面）制御も可能であることを，これまでに見出 している. 本研究では部分的選択キャッピング水熱法により, 高活性な結晶面を有する固体酸化物 形燃料電池 (SOFC) 用希土類ドープセリア (GDC) ナノキューブを合成した。また, GDCナノキュー ブと酸化ニッケルナノ粒子（NiO） を複合・集積化させた SOFC 燃料極用コンポジットナノ粒子を

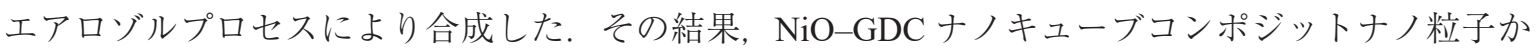
ら作製したニッケル系サーメット燃料極は，世界トップの電極性能を有することを実証した。ささら に，液相還元合成した金属ニッケル（Ni)-GDCナノキューブコンポジットナノ粒子から作製した 新規燃料極（発電試験時の in-situ 焼付けにより GDCナノキューブの構造・機能が維持）は, これ までに開発した上記の高性能燃料極と比較して，分極值をさらに $1 / 3$ 程度まで低減できることを実 証した。

\begin{abstract}
A core-shell anode consisting of nickel-gadolinium-doped-ceria (Ni-GDC) nanocubes was directly fabricated by a chemical process in a solution containing a nickel source and GDC nanocubes covered with highly reactive $\{001\}$ facets. The cermet anode effectively generated a Ni metal framework even at $500^{\circ} \mathrm{C}$ with the growth of the Ni spheres. Anode fabrication at such a low temperature without any sintering could insert a finely nanostructured layer close to the interface between the electrolyte and the anode. The maximum power density of the attractive anode was $97 \mathrm{~mW} \cdot \mathrm{cm}^{-2}$, which is higher than that of a conventional NiOGDC anode prepared by an aerosol process at $55 \mathrm{~mW} \cdot \mathrm{cm}^{-2}$ and $600^{\circ} \mathrm{C}$, followed by sintering at $1300^{\circ} \mathrm{C}$. Furthermore, the macro- and microstructure of the Ni-GDC-nanocube anode were preserved before and after the power-generation test at $700^{\circ} \mathrm{C}$. Especially, the reactive $\{001\}$ facets were stabled even after generation test, which served to reduce the activation energy for fuel oxidation successfully.
\end{abstract}




\section{研究背景と目的}

本研究代表者はセラミックスや金属ナノクリ スタルの新規化学プロセスの開発に着手してい る，水熱反応場に有機分子等を共存させ，その キャッピング接合により無機ナノクリスタルの サイズ・形状 (結晶面) ・ 結晶構造等を制御する

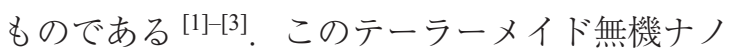
クリスタルは従来の同じ物質を凌駕する機能や 新規物性の発現が確認されはじめている ${ }^{[4]-[6]}$. そこで本研究ではテーラーメイド無機ナノクリ スタルを活用した低温作動固体酸化物形燃料電 池（Solid Oxide Fuel Cell: SOFC）の開発に向け, 高性能化のためのナノクリスタルの高次構造制 御や複合・集積化に関する研究を行った，具体 的には, 高次構造制御した希土類ドープセリア （GDC）ナノキューブの低温作動 SOFC 用燃料 極への応用を検討した。

\section{研 究 方 法}

セリア $\left(\mathrm{CeO}_{2}\right)$ に希土類（例えば $\mathrm{Gd}_{2} \mathrm{O}_{3}$ )を ドープすると酸化物イオン導電性が発現するた め, 希土類ドープセリア（GDC）は低温作動 SOFC の代表的な構成材料である。これまでに 希土類ドープセリアナノクリスタルのサイズ . 形状（結晶面）制御を検討し，6アミノへキサ ン酸を用いた部分的な選択キャッピング（図 1) により高活性な (001) 面を持つ GDCナノキュー ブ（図 2）の水熱合成に成功している ${ }^{[7]}$ 。本研 究では合成したナノキューブを燃料極に適用 $L^{[8]}$, 現状の発電性能を凌駕する超高性能な次 世代の低温作動 SOFC の開発を目指している。

なお，無機ナノクリスタルの特異的な機能を 十分に発揮するには，それらを凝集することな く所望の媒体中に完全に分散させることが大前 提となる。すすおち，ナノ粒子の表面制御およ び完全分散技術がその本格的実用化を迎える上 でブレイクスルーすべき最重要課題であった。 これに対し，本研究で合成された無機ナノクリ スタルは表面修飾された有機分子により溶媒中

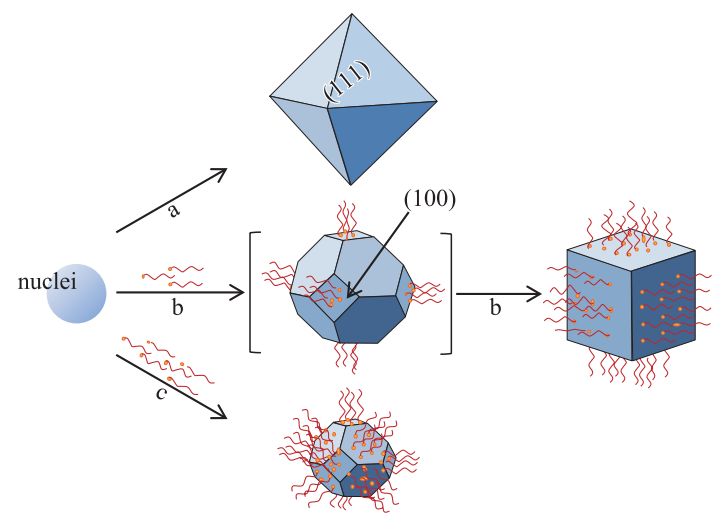

Fig. 1 The shape control of $\mathrm{CeO}_{2}$ nanocrystals. (a) A octahedron in the case when no organic-ligandmolecules are used. (b) At a low organic-ligandmolecules to $\mathrm{CeO}_{2}$ precursor ratio, the preferential interaction of the ligand-molecules with the $\mathrm{CeO}_{2}$ $\{001\}$ planes slows the growth of $\{001\}$ faces relative to $\{111\}$ faces, which leads to the formation of nanocubes. (c) At a high organicligand-molecules to $\mathrm{CeO}_{2}$ precursor ratio, ligandmolecules block growth on both $\{001\}$ faces and $\{111\}$ faces, which leads to the formation of truncated octahedral crystals.
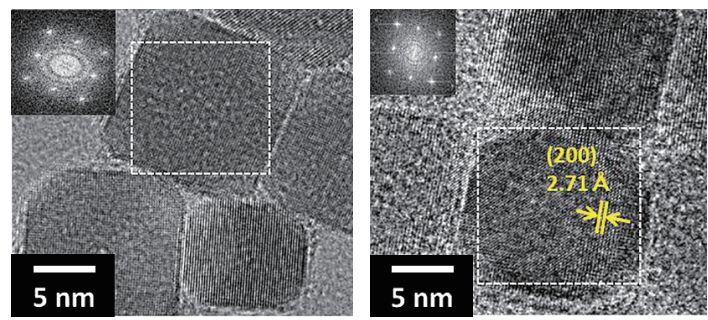

Fig. 2 HRTEM image of $\mathrm{CeO}_{2}$ (left) and Gd-doped $\mathrm{CeO}_{2}$ (GDC: right) nanocubes.

に完全（透明）分散するため, ナノクリスタル のハンドリング性・分散性が著しく向上できて いる（図 3）.

\section{研 究成果}

SOFC 燃料極には希土類ドープセリアとニッ ケルを複合化させたサーメットが広く使用され る。合成した希土類ドープセリア（GDC）ナ ノキューブは水中に完全分散するため（図 3）, ニッケル原料となる水溶液と均一相を形成でき る。そこでエアロゾルプロセスにより GDCナ 


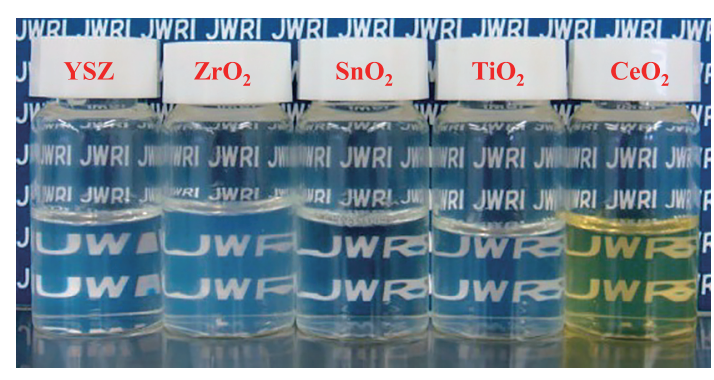

Fig. 3 Dispersion behavior of ceramics nanocrystals in water.

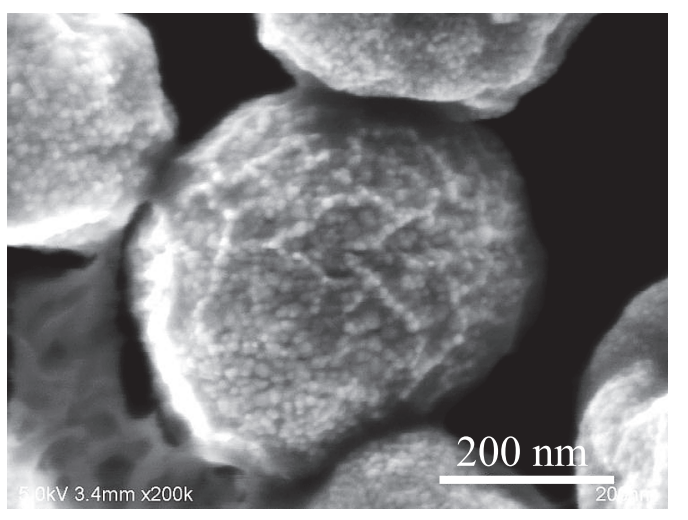

Fig. 4 SEM image of NiO-GDC nanocube composite nanoparticles.

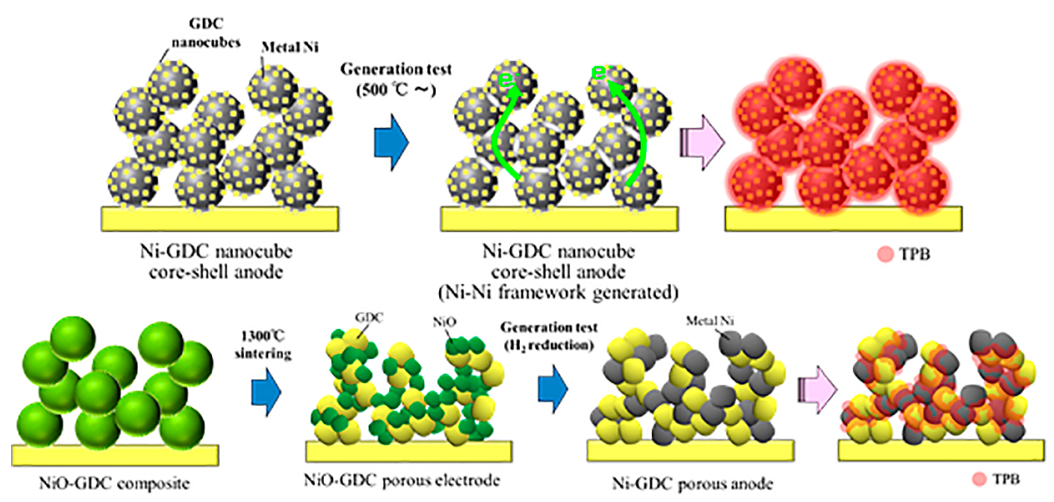

Fig. 5 Scheme of new (up) and conventional (down) Ni-GDC anodes.

ノキューブと酸化ニッケル（NiO）ナノ粒子を 複合化させた低温作動 SOFC 然料極用コンポ ジットナノ粒子（図 4）を合成し，燃料極性 能の高性能化を試みた。 その結果，世界トップ レベルの電極性能 (Area-Specific Resistance: $\mathrm{ASR}=0.14 \Omega \cdot \mathrm{cm}^{2}\left(600^{\circ} \mathrm{C}\right.$ 作動 $\left.)\right)$ が実現できた。

さらに，液相還元プロセスによりGDCナノ キューブと金属ニッケル $(\mathrm{Ni})$ ナノ粒子（従来 は酸化ニッケル（NiO）ナノ粒子）を複合化さ せた新規 SOFC 燃料極用コンポジットナノ粒子 を合成し，燃料極性能の超高性能化を試みた。 その結果, 上記の高性能燃料極（NiO-GDCナ ノキューブコンポジットナノ粒子（図 4) $1100^{\circ} \mathrm{C}$ 焼付けで作製) と比較して，ASRをさ らに低減 $\left(0.05 \Omega \cdot \mathrm{cm}^{2}\left(600^{\circ} \mathrm{C}\right.\right.$ 作動 $\left.)\right)$ できるこ とを見出した。これは, 発電試験時の in-situで の低温焼付け（例えば $600^{\circ} \mathrm{C}$ )によりナノキュー ブの構造・機能が維持されたことによるものと
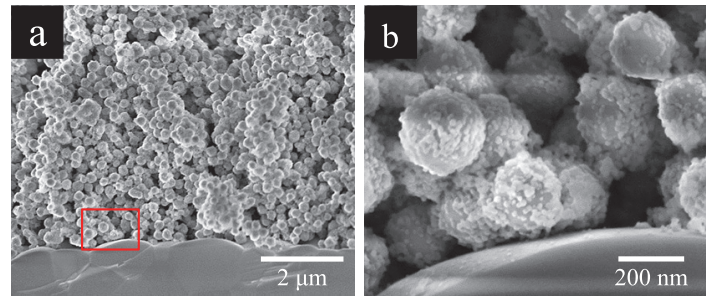

Fig. 6 Cross-sectional microscope images of Ni-GDC nanocube anode after power generation test.

考えている(図 5).

また, 実用化の観点から, 開発した超高性能 燃料極の長期安定性の評価を行った。まず, $600^{\circ} \mathrm{C}-24$ 時間の発電性能評価を行った結果, 発電試験後であっても燃料極全体のミクロ構造 には変化が見られなかった（図6（a））。また， 然料極のナノ構造を観察したところ (図6 (b)), 球状金属 $\mathrm{Ni}$ の表面に微細な GDCナノキュー ブ粒子が被覆されている様子が確認できた。こ 
のように，本超高性能 $\mathrm{Ni}-\mathrm{GDC}$ 燃料極は $600^{\circ} \mathrm{C}$ 作動では安定性を有することが明らかとなった。

\section{参考文献}

[1] Zhang J., Ohara S., Umetsu M., Naka T., Hatakeyama Y., Adschiri T., Colloidal ceria nanocrystals: A tailormade crystal morphology in supercritical water, Advanced Materials, 19 (2007) 203-206. https://doi.org/10.1002/adma.200600964

[2] Sato K., Abe H., Ohara S., Selective growth of monoclinic and tetragonal zirconia nanocrystals, Journal of the American Chemical Society, 132 (2010) 25382539. https://doi.org/10.1021/ja910712r

[3] Qiu N., Zhang J., Zheng L., Chang G., Hashishin T., Ohara S., Wu Z., Surface-binding-mediated growth of monodisperse cobalt-doped ceria nanocrystals, RSC Advances, 4 (2014) 16033-16038. https://doi.org/10.1039/C3RA47661H

[4] Zhang J., Kumagai H., Yamamura K., Ohara S., Takami S., Morikawa A., Shinjoh H., Kaneko K., Adschiri T., Suda A., Extra-low-temperature oxygen storage capacity of $\mathrm{CeO}_{2}$ nanocrystals with cubic facets, Nano Letters,

\section{外部発表成果}

$$
\text { 口頭・ポスター発表 }
$$

1. S. Ohara, "Synthesis of Tailor-Made Ceramic Nanocrystals by Organic Ligand-Assisted Hydrothermal Method towards Environmental Applications", The $3^{\text {rd }}$ International Symposium on Creation of Life Innovation Materials for Interdisciplinary and International Researcher Development (iLIM-3) (Tokyo, Japan, Sept. 25, 2018).

2. S. Ohara, "High-Performance Ni Nanocomposite Anode Fabricated from Gd-doped Ceria Nanocubes for Low-Temperature Solid-Oxide Fuel Cells", 6th Nano Today Conference
11 (2011) 361-364. https://doi.org/10.1021/nl102738n

[5] Zhang J., Naka T., Ohara S., Kaneko K., Trevethan T., Shluger A., Adschiri T., Surface ligand assisted valence change in ceria nanocrystals, Physical Review B, 84 (2011) 045411.

https://doi.org/10.1103/PhysRevB.84.045411

[6] Tan Z., Sato K., Takami S., Numako C., Umetsu M., Soga K., Nakayama M., Sasaki R., Tanaka T., Ogino C., Kondo A., Yamamoto K., Hashishin T., Ohara S., Particle size for photocatalytic activity of anatase $\mathrm{TiO}_{2}$ nanosheets with highly exposed $\{001\}$ facets, RSC Advances, 3 (2013) 19268-19271. https://doi.org/10.1039/C3RA43383H

[7] Yamamoto K., Hashishin T., Matsuda M., Qiu N., Tan Z., Ohara S., High-performance Ni nanocomposite anode fabricated from Gd-doped ceria nanocubes for low-temperature solid-oxide fuel cells, Nano Energy, 6 (2014) 103-108.

https://doi.org/10.1016/j.nanoen.2014.03.007

[8] Yamamoto K., Qiu N., Ohara S., In situ fabrication of high-performance Ni-GDC-nanocube core-shell anode for low-temperature solid-oxide fuel cells, Scientific Reports, 5 (2015) 17433. https://doi.org/10.1038/srep17433

(Lisbon, Portugal, June 18, 2019).

3. S. Ohara, "Synthesis of Tailor-Made Ceramic Nanocrystals by Organic Ligand-Assisted Hydrothermal Method towards Energy and Environmental Applications", 15th IUPAC International Conference on Novel Materials and their Synthesis (NMS 2019) (Shenyang, China, Sept. 8, 2019) [Invited lecture].

4. S. Ohara, "Synthesis of Tailor-Made Ceramic Nanocrystals by Organic Ligand-Assisted Hydrothermal Method towards Environmental and Energy Applications", International Symposium on Creation of Life Innovation Materials for Interdisciplinary and International Researcher Development Satellite (iLIM-s) (Nagoya, Japan, Nov. 2, 2019). 